\title{
Synergistic Effect of Cationic Surfactants in Adsorption
}

\author{
T.Kasilingam ${ }^{1}$ and C.Thangavelu ${ }^{2, *}$ \\ ${ }^{1}$ Department of Chemistry, Theivanai Ammal College for Womenc(Autonomous), Villupuram, \\ Tamil Nadu, India \\ ${ }^{2}$ Department of Chemictry, Periyar E. V. R. College (Autonomous), Tiruchirappalli, Tamilnadu, \\ India.
}

thavankasi@gmail.com,drkctv@gmail.com

Keywords: carbon steel, surfactants, weight loss, electrochemical methods, FTIR

\begin{abstract}
The corrosion behaviour of cationic surfactants, namely: cetyl trimethyl ammonium bromide (CTAB) and dodecyl trimethyl ammonium bromide (DTAB), have been used as corrosion inhibitors for carbon steel in well water. Protection efficiencies of the studied surfactants were depended on the hydrophobic chain length and concentration of the surfactants. The results shows that the order of protection efficiency is CTAB $>$ DTAB. Tafel curves showed these surfactants are acting as an anodic inhibitors. Nyquist curves revealed that a protective film is formed on the metal surface. FTIR spectra suggest that the tested surfactants protective film consists of $\mathrm{Fe}^{2+}-\mathrm{CTAB}$, $\mathrm{Fe}^{2+}$-DTAB and $\mathrm{Zn}(\mathrm{OH})_{2}$. Protection efficiency values and synergism parameters obtained weight loss; potentiodynamic polarization and electrochemical impedance spectroscopy are consistent.
\end{abstract}

\section{Introduction}

Iron-based alloys are used in different applications and they are susceptible to corrosion due to its thermodynamic instability especially in aggressive media. A variety of attempts have been made to prevent/retard the destructive effect of corrosion on metals and alloys. Corrosion control can be achieved by various methods, corrosion inhibition being one of the most effective alternatives [1,2]. Surfactants are special type of organic compounds and exhibit unique properties due to their amphiphilic structure, consisting of hydrophilic and hydrophobic molecular segments. They form hydrophobic barrier film as a result of the interaction of hydrophilic side with the metal surface, which prevents direct contact between metal surface and corrosive environment. The surfactant inhibitors have many advantages, such as being environmentally friendly, high efficiency, low price and availability [3-5].

Adsorption of surfactants on metal surface can markedly increase the corrosion-resistance [6] and therefore the study of the relationship between the adsorption and corrosion inhibition is of great importance.

The adsorption of a surfactant markedly changes the corrosion resisting property of a metal, and for these reasons studies of the relation between adsorption and corrosion inhibition are of considerable importance [7-10]. In corrosion inhibition with surfactant inhibitors, the critical micelle concentration (CMC) is the most important parameter. When the concentration of surfactant adsorbed on the solid surface is high enough, organized structures (hemi-micelles such as bi-or multilayer) are formed, which decrease the corrosion reaction by blocking the metallic surface [1113]. The objective of this work is to study the effect of investigated surfactants on the protection of corrosion of carbon steel in well water.

\section{Materials and Methods}

Materials. Carbon steel used for corrosion inhibition studies the compositions was (Wt\%): $0.026 \% \mathrm{~S}, \quad 0.06 \% \mathrm{P}, 0.4 \% \mathrm{Mn}, 0.1 \% \mathrm{C}$ and balance being Fe. Specimens of size $1.0 \mathrm{~cm} \times 4.0 \mathrm{~cm} \times 0.2 \mathrm{~cm}$ were press cut from the carbon steel sheet, were machined and abraded with a series of emery papers. This was followed by rinsing in acetone and double distilled water and 
finally dried in air. Before any experiment, the substrates were treated as described and freshly used with no further storage. The inhibitors $\mathrm{CTAB}$ and $\mathrm{DTAB}$, molecular structure formula of CTAB and DTAB are shown in Table $1 . \mathrm{Zn}^{2+}$ ions were used as received.

Table 1: Molecular and Structure formula of CTAB and DTAB

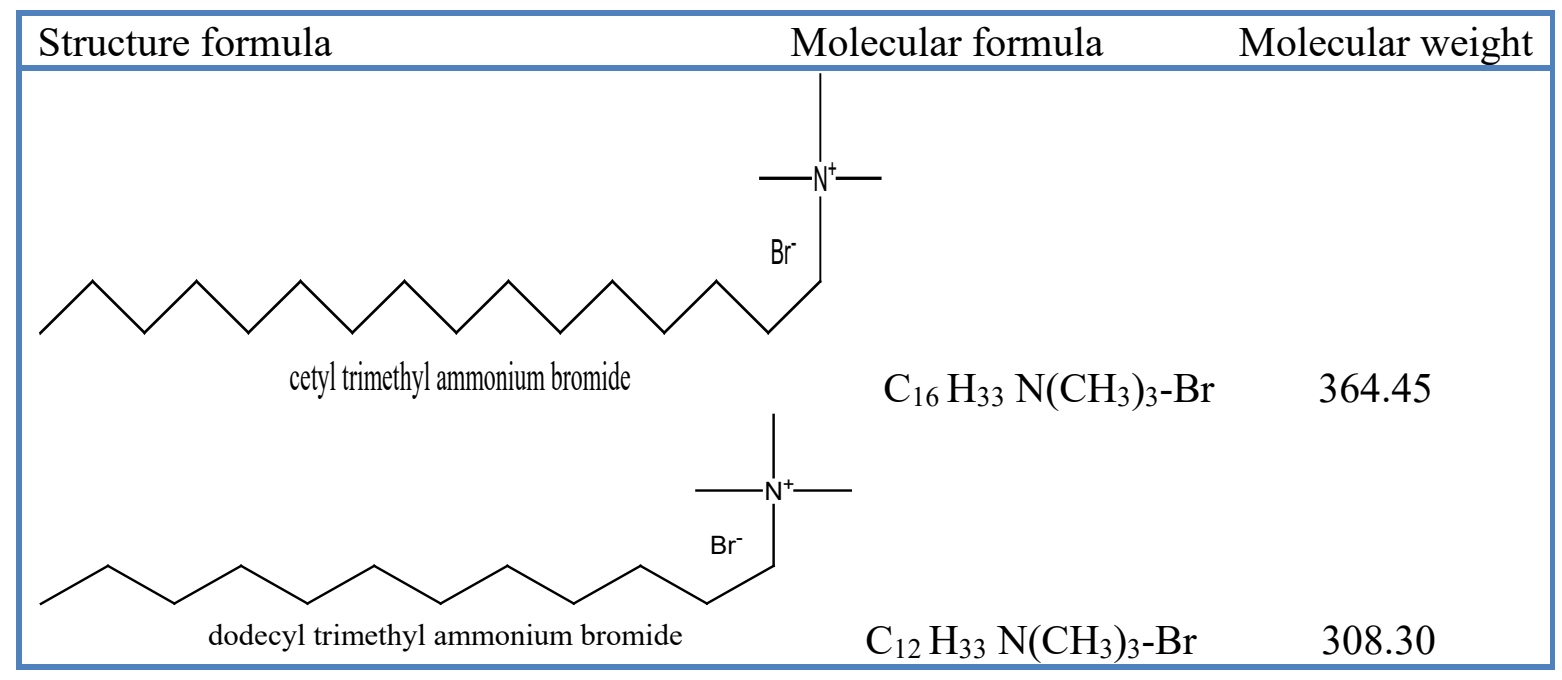

Stock solution of $1000 \mathrm{ppm}$ of CTAB was prepared in double distilled water and the desired concentration was obtained by appropriate dilution. The concentration of CTAB used for the study ranges from 10 to $150 \mathrm{ppm}$. The study was carried out at room temperature in open atmosphere.

Weight - loss Measurements. Carbon steel specimens were suspended in $150 \mathrm{~mL}$ beakers containing $100 \mathrm{~mL}$ of test solution maintained at room temperature with the aid of glass rods and hooks. The weight loss taken was the difference between the weight at a given time and the original weight of the specimens. The measurements were carried out for the uninhibited solution and the solution containing CTAB, CTAB $-\mathrm{Zn}^{2+}$, DTAB and DTAB $-\mathrm{Zn}^{2+}$ mixture. Weight loss experiments were performed for the seven days duation. The specimens were immersed in triplicate and the average corrosion rate was calculated.

These uncertainties or RSD for three replicate measurements were less than $5 \%$. The corrosion rates $\left(\mathrm{C}_{\mathrm{R}}\right)$ were measured using the equation:

$$
\text { Corrosion Rate }\left(\frac{m m}{y}\right)=\frac{87.6 \times W}{\text { AT D }}
$$

Where $\mathrm{W}=$ weight loss of carbon steel $(\mathrm{mg})$

$\mathrm{A}=$ area of the specimens $\left(\mathrm{cm}^{2}\right)$

$\mathrm{T}=$ exposure time $(\mathrm{h})$

$\mathrm{D}=$ density of the specimen $\left(\mathrm{g} \mathrm{cm}^{-3}\right)$.

The inhibition efficiency (IE) of $\mathrm{CTAB}$ and $\mathrm{Zn}^{2+}$ mixture was calculated by using the following equation:

$$
\% I E=\frac{C R o-C R i}{C R o}
$$

Where $\mathrm{CRo}=$ corrosion rate in the absence of inhibitor

$\mathrm{CRi}=$ corrosion rate in the presence of inhibitor

Surface analysis by FTIR spectroscopy. The specimen immersed the one day duration in various environments, the specimens were taken out of the test solution and dried. The film formed on the surface was scratched carefully and it was thoroughly mixed so as to make it uniform throughout. 
FTIR spectrum of the powder (KBr Pellets) was record using perkin-elmer-1600 FTIR spectrophotometer with resolving power of $4 \mathrm{~cm}^{-1}$.

Electrochemical studies. Electrochemical studies were carried out using the electrochemical workstation model CHI- 760d and experimental data were analysed by using the electrochemical software (Version: 12.22.0.0). Measurements were conducted in a conventional three electrode cylindrical glass cell with platinum electrode as auxiliary electrode and saturated calomel electrode as reference electrode.

The working electrode was carbon steel embedded in epoxy resin of polytetrafluoroethylene so that the flat surface of $1 \mathrm{~cm}^{2}$ was the only surface exposed to the electrolyte solutions.

The three electrodes set up was immersed in control solution of volume $100 \mathrm{ml}$ both in the absence and presence of the inhibitors formulations and allowed to attain a stable open circuit potential (OCP). The $\mathrm{pH}$ values of the solution were adjusted to 7.0 and the solutions were unstirred during the experiments.

Tafel curves were recorded in the potential range of -750 to $-150 \mathrm{mV}$ with a resolution of $2 \mathrm{mV}$. The curves were recorded in the dynamic scan mode with a scan rate of $2 \mathrm{mVS}^{-1}$ in the current range of $-20 \mathrm{~mA}$ to $+20 \mathrm{~mA}$. The Ohmic drop compensation has been made during the studies. The corrosion potential $\left(\mathrm{E}_{\text {corr }}\right)$, corrosion current $\left(\mathrm{I}_{\mathrm{corr}}\right)$, anodic Tafel slope $\left(\beta_{\mathrm{a}}\right)$ and cathodic Tafel slope $\left(\beta_{c}\right)$ were obtained by extrapolation of anodic and cathodic regions of the Tafel plots. The inhibition efficiency $\left(\mathrm{IE}_{\mathrm{p}}\right)$ values were calculated from the $\mathrm{I}_{\mathrm{corr}}$ values using the equation.

$$
\mathrm{IE}_{\mathrm{p}}(\%)=\left[1-\left(\mathrm{I}_{\text {corr }}^{\prime} / \mathrm{I}_{\text {corr }}\right)\right] \times 100
$$

Where $\mathrm{I}_{\text {corr }}$ and $\mathrm{I}_{\text {corr }}$ are the corrosion current densities in case of control and inhibited solutions respectively.

Nyquist plots were recorded at OCP in the frequency range from $60 \mathrm{KHz}$ to $10 \mathrm{MHz}$ with 4 to 10 steps per decade. A sine wave, with $10 \mathrm{mV}$ amplitude, was used to perturb the system. The impedance parameters viz., charge transfer resistance $\left(R_{c t}\right)$, double layer capacitance $\left(C_{d l}\right)$ were obtained from the Nyquist plots. The inhibition efficiencies $\left(\mathrm{IE}_{\mathrm{i}}\right)$ were calculated using the equation,

$$
\mathrm{IE}_{\mathrm{i}}(\%)=100\left[1-\mathrm{R}_{\mathrm{ct}} / \mathrm{R}_{\mathrm{ct}}^{\prime}\right]
$$

Where $R_{c t}$ and $R_{c t}^{\prime}$ are the charge transfer resistance values in the presence and absence of the inhibitor respectively.

\section{Results and Discussion}

\section{Weight - loss measurements}

Information of Table 2 shows that, protection efficiency dependence on the altering concentration of surfactants in the range from $10 \mathrm{ppm}$ to $150 \mathrm{ppm}$. It is apparently that, at room temperature the protection efficiency increases with raising concentration of the each surfactant. The lowest corrosion rate is obtained by CTAB therefore I.E tends to decrease in the following order $\mathrm{CTAB}>\mathrm{DTAB}$. This action was attributed to effect of alkyl chain length. Co-adsorption $\left(\mathrm{Zn}^{2+}\right)$ acts as a good synergism attain in surfactants 
Table 2: Weight - loss measurements for carbon steel in well water without and with an inhibitor of different concentration of surfactants at room temperature

\begin{tabular}{|c|c|c|c|c|c|c|}
\hline $\begin{array}{l}\text { Name of } \\
\text { surfactant }\end{array}$ & $\begin{array}{l}\text { Conc. of } \\
\mathrm{Zn}^{2+}(\mathrm{ppm})\end{array}$ & $\begin{array}{l}\text { Conc. of } \\
\text { surfactant } \\
\text { (ppm) }\end{array}$ & $\mathrm{C}_{\mathrm{R}}\left(\mathrm{mmy}^{-1}\right)$ & $\% \mathrm{IE}$ & $\begin{array}{c}\text { Surface } \\
\text { coverage }(\theta)\end{array}$ & Synergism $\left(\mathrm{S}_{\mathrm{I}}\right)$ \\
\hline \multirow{16}{*}{ CTAB } & Blank & - & 194.4 & - & - & - \\
\hline & 25 & - & 155.5 & 20 & 0.20 & - \\
\hline & - & 10 & 188.6 & 3 & 0.03 & - \\
\hline & - & 25 & 178.9 & 8 & 0.08 & - \\
\hline & - & 50 & 171.1 & 12 & 0.12 & - \\
\hline & - & 75 & 163.3 & 16 & 0.16 & - \\
\hline & - & 100 & 155.5 & 20 & 0.20 & - \\
\hline & - & 125 & 149.7 & 23 & 0.23 & - \\
\hline & - & 150 & 141.1 & 27 & 0.27 & - \\
\hline & 25 & 10 & 143.9 & 26 & 0.26 & 1.0486 \\
\hline & 25 & 25 & 130.3 & 33 & 0.33 & 1.0985 \\
\hline & 25 & 50 & 114.7 & 41 & 0.41 & 1.1932 \\
\hline & 25 & 75 & 93.3 & 52 & 0.52 & 1.4000 \\
\hline & 25 & 100 & 62.2 & 68 & 0.68 & 2.0000 \\
\hline & 25 & 125 & 44.7 & 77 & 0.77 & 2.6782 \\
\hline & 25 & 150 & 17.5 & 91 & 0.91 & 6.4889 \\
\hline \multirow{14}{*}{ DTAB } & - & 10 & 196.4 & -1 & 0.01 & - \\
\hline & - & 25 & 182.0 & 6 & 0.06 & - \\
\hline & - & 50 & 175.0 & 10 & 0.10 & - \\
\hline & - & 75 & 149.7 & 23 & 0.23 & - \\
\hline & - & 100 & 163.3 & 16 & 0.16 & - \\
\hline & - & 125 & 171.1 & 12 & 0.12 & - \\
\hline & - & 150 & 178.9 & 8 & 0.08 & - \\
\hline & 25 & 10 & 151.6 & 22 & 0.22 & 1.03 \\
\hline & 25 & 25 & 134.1 & 31 & 0.31 & 1.08 \\
\hline & 25 & 50 & 101.1 & 48 & 0.48 & 1.38 \\
\hline & 25 & 75 & 42.7 & 78 & 0.78 & 2.80 \\
\hline & 25 & 100 & 70.0 & 64 & 0.64 & 1.86 \\
\hline & 25 & 125 & 83.6 & 53 & 0.53 & 1.49 \\
\hline & 25 & 150 & 108.9 & 44 & 0.44 & 1.31 \\
\hline
\end{tabular}

\section{FTIR spectroscopy}

FTIR spectra powerful technique for find out the functional group were recorded to understand the interaction of inhibitor molecule with the metal. Figs. 2 and 3 shows the IR spectra of pure and scraped samples of surfactants obtained from after corrosion experiments in well water respectively.

Pure CTAB, the IR peak observed at $621 \mathrm{~cm}^{-1}$ has been assigned to C-Br of CTAB. Scraped sample, the IR peaks that appeared at $572 \mathrm{~cm}^{-1}$ and $1382 \mathrm{~cm}^{-1}$ have been assigned to $\mathrm{C}-\mathrm{Br}$ and $\mathrm{Zn}$ - O. All the peaks displayed substantial shift with fairly low or high intensity indicating coordination through carbon and bromine of CTAB moiety. It is therefore inferred that CTAB and $\mathrm{Zn}^{2+}$ are involved in complex formation with $\mathrm{Fe}^{2+}$ as well as $\mathrm{Zn}^{2+}$ and the presence of $\left[\mathrm{Fe}^{2+}-\mathrm{Zn}^{2+}-\right.$ $\mathrm{CTAB}]$ and $\mathrm{Zn}(\mathrm{OH})_{2}$

Similarly, pure DTAB the IR peak observed at $530.42 \mathrm{~cm}^{-1}$ has been assigned to C-Br of DTAB. Scraped sample, the IR peaks that appeared at $470.63 \mathrm{~cm}^{-1}$ and $1381 \mathrm{~cm}^{-1}$ have been assigned to $\mathrm{C}-\mathrm{Br}$ and $\mathrm{Zn}-\mathrm{O}$ [14-16]. All the peaks displayed substantial shift with fairly low or high intensity indicating coordination through carbon and bromine of DTAB moiety, it is therefore inferred that 
DTAB and $\mathrm{Zn}^{2+}$ are involved in complex formation with $\mathrm{Fe}^{2+}$ as well as $\mathrm{Zn}^{2+}$ and the presence of $\left[\mathrm{Fe}^{2+}-\mathrm{Zn}^{2+}-\mathrm{DTAB}\right]$ and $\mathrm{Zn}(\mathrm{OH})_{2}$.

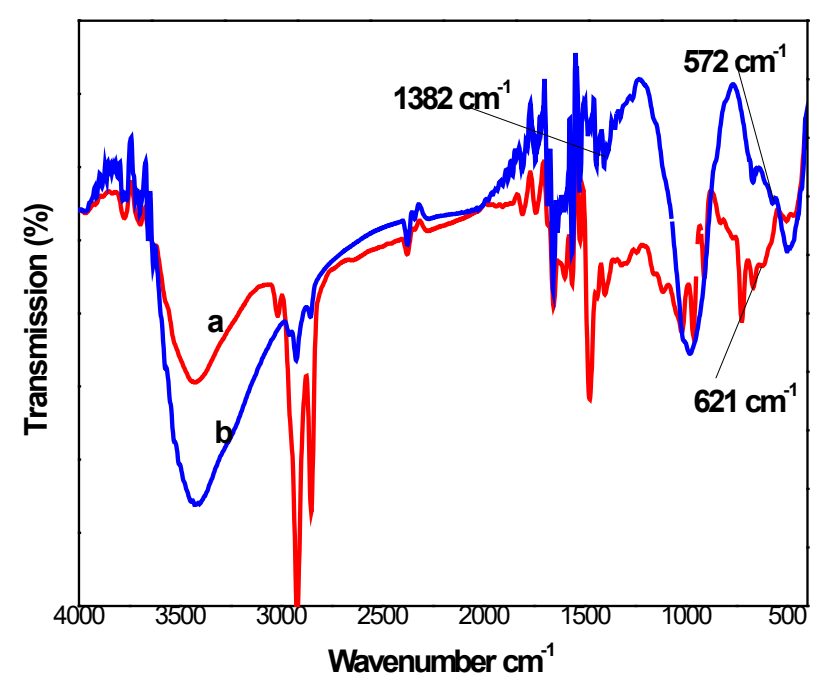

Figure 1: FTIR spectrum of CTAB a) Pure sample b) Scraped sample

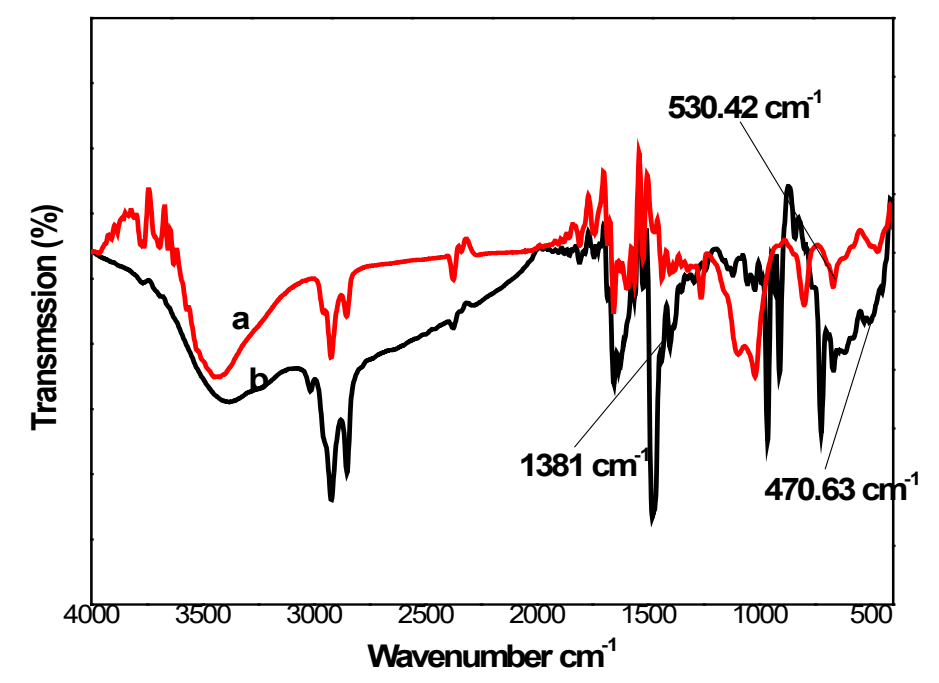

Figure 2: FTIR spectrum of DTAB a) Pure sample b) Scraped sample

\section{Tafel curves}

Datas of corrosion current density ( $\left.\mathrm{I}_{\text {corr }}\right)$, corrosion potential $\left(\mathrm{E}_{\mathrm{corr}}\right)$, anodic slope $\left(\beta_{\mathrm{a}}\right)$ and cathodic slope $\left(\beta_{c}\right)$ can be evaluated from anodic and cathodic region of the Tafel curves. The linear Tafel segments of anodic and cathodic plots were extrapolated to obtain corrosion current ( $\mathrm{I}_{\text {corr }}$ ).

Figs. 3 and 4 represent the Tafel curves of carbon steel in well water, without and with an inhibitor formulation of the CTAB and DTAB. It can see from Figs. 3 and 4 that, with inhibitors, the curves are shifted to lower current regions, showing the inhibition tendency of the surfactants. There was definite trend observed in the $E_{\text {corr }}$ values in the presence of both the surfactants. In the present study, shift in $\mathrm{E}_{\text {corr }}$ values in more positive zones suggesting that they all acts as anodic inhibitors. 


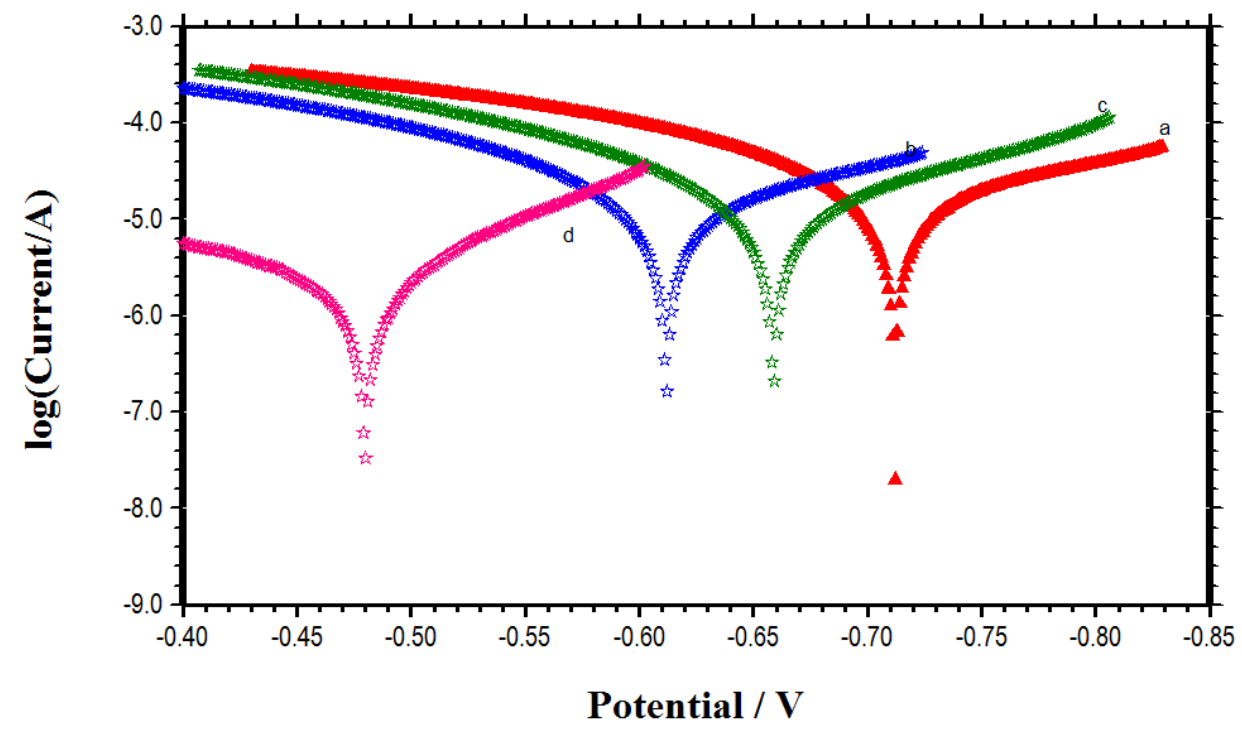

Figure 3: Tafel curves a) Blank b) 25ppm $\mathrm{Zn}^{2+}$ c) 150ppm CTAB d) $25 \mathrm{ppm} \mathrm{Zn}^{2+}+150 \mathrm{ppm} \mathrm{CTAB}$

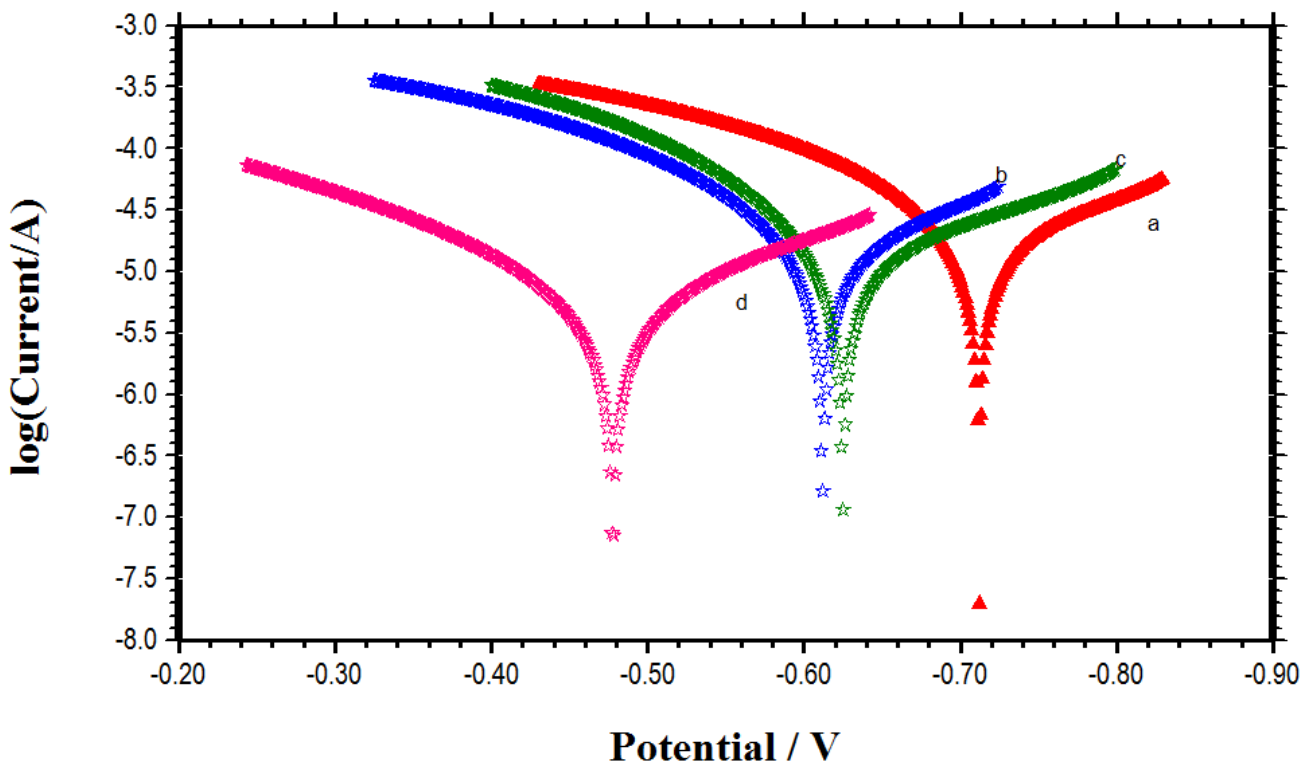

Figure 4: Tafel curves a) Blank b) 25ppm $\mathrm{Zn}^{2+}$ c) $75 \mathrm{ppm}$ DTAB d) $25 \mathrm{ppm} \mathrm{Zn}^{2+}+75 \mathrm{ppm}$ DTAB

The values of various electrochemical parameters derived by Tafel plots of the inhibitors are given in Table 3. Investigation Table 3 revealed that the values of $\beta_{c}$ change slightly in the presence of both the inhibitor formulations, whereas a more change occurs in the values of $\beta_{a}$, indicating that anodic reactions are affected. Thus, both the CTAB and DTAB acted as anodic corrosion inhibitors. The data obtained from fitted spectra are listed in Tables 3 and 4. The inhibition efficiency, surface coverage $(\theta)$ and synergism parameters are calculated from the Tafel plots by using following equation:

$$
\mathrm{S}_{\mathrm{I}}=\left(1-\mathrm{I}_{1+2}\right) /\left(1-\mathrm{I}_{1+2}^{\prime}\right)
$$

Where

$\mathrm{I}_{1+2}=\left(\mathrm{I}_{1}+\mathrm{I}_{2}\right)-\left(\mathrm{I}_{1 \times \mathrm{I}_{2}}\right)$

$\mathrm{I}_{1}=$ surface coverage of inhibitors (surfactants)

$\mathrm{I}_{2}=$ surface coverage of inhibitors $\left(\mathrm{Zn}^{2+}\right)$

$\mathrm{I}_{1+2}^{\prime}=$ combined surface coverage of inhibitors (surfactants) and $\left(\mathrm{Zn}^{2+}\right)$ 
Table 3: Electrochemical parameters, inhibition efficiency (IE) and synergism parameter $\left(\mathrm{S}_{\mathrm{I}}\right)$ from the polarization study for carbon steel in well water

\begin{tabular}{|c|c|c|c|c|c|c|c|c|}
\hline $\begin{array}{c}\text { Conc. } \\
\text { of } \mathrm{Zn}^{2+} \\
(\mathrm{ppm})\end{array}$ & $\begin{array}{c}\text { Conc. of } \\
\text { CTAB } \\
(\mathrm{ppm})\end{array}$ & $\begin{array}{c}-\mathrm{E}_{\text {corr }} \\
\mathrm{mV} \text { vs } \\
\mathrm{SCE}\end{array}$ & $\begin{array}{c}\beta_{\mathrm{a}} \mathrm{mV} \\
\mathrm{dec}^{-1}\end{array}$ & $\begin{array}{c}\beta_{\mathrm{c}} \mathrm{mV} \\
\mathrm{dec}^{-1}\end{array}$ & $\begin{array}{c}\mathrm{I}_{\text {corr, }} \\
\mathrm{A} . \mathrm{Cm}^{-2}, \\
\times 10^{-5}\end{array}$ & $\begin{array}{c}\mathrm{IE}_{\mathrm{pol}}, \\
\%\end{array}$ & $\begin{array}{c}\text { Surface } \\
\text { coverage } \\
(\theta)\end{array}$ & $\begin{array}{c}\text { Synergis } \\
\mathrm{m}\left(\mathrm{S}_{\mathrm{I}}\right)\end{array}$ \\
\hline Blank & - & -712 & 2.676 & 170.3 & 198.4 & - & - & - \\
\hline- & 25 & -612 & 2.158 & 154.7 & 180.5 & 19.35 & 0.1935 & - \\
\hline 150 & - & -655 & 1.988 & 149.7 & 156.9 & 25.71 & 0.2571 & - \\
\hline 150 & 25 & -480 & 0.254 & 236.9 & 106.0 & 90.50 & 0.9050 & 6.3063 \\
\hline
\end{tabular}

Table 4: Electrochemical parameters, inhibition efficiency (IE) and synergism parameter $\left(\mathrm{S}_{\mathrm{I}}\right)$ from the polarization study for carbon steel in well water

\begin{tabular}{|c|c|c|c|c|c|c|c|c|}
\hline $\begin{array}{c}\text { Conc. } \\
\text { of } \mathrm{Zn}^{2+} \\
(\mathrm{ppm})\end{array}$ & $\begin{array}{c}\text { Conc. of } \\
\mathrm{DTAB} \\
(\mathrm{ppm})\end{array}$ & $\begin{array}{c}-\mathrm{E}_{\mathrm{corr}} \mathrm{mV} \\
\text { vs SCE }\end{array}$ & $\begin{array}{c}\beta_{\mathrm{a}} \mathrm{mV} \\
\mathrm{dec}^{-1}\end{array}$ & $\begin{array}{c}\beta_{\mathrm{c}} \mathrm{mV} \\
\mathrm{dec}^{-1}\end{array}$ & $\begin{array}{c}\mathrm{I}_{\text {corr, }} \\
\mathrm{A} \cdot \mathrm{Cm}^{-2}, \\
\times 10^{-5}\end{array}$ & $\begin{array}{c}\mathrm{IE}_{\mathrm{pol}}, \\
\%\end{array}$ & $\begin{array}{c}\text { Surface } \\
\text { coverage } \\
(\theta)\end{array}$ & $\begin{array}{c}\text { Synergis } \\
\mathrm{m}\left(\mathrm{S}_{\mathrm{I}}\right)\end{array}$ \\
\hline Blank & - & -712 & 2.676 & 170.3 & 198.4 & - & - & - \\
\hline- & 25 & -612 & 2.158 & 154.7 & 180.5 & 19.35 & 0.1935 & - \\
\hline 75 & - & -625 & 2.081 & 136.0 & 233.1 & 22.23 & 0.2223 & - \\
\hline 75 & 25 & -478 & 0.591 & 158.2 & 193.7 & 77.91 & 0.7791 & 2.8392 \\
\hline
\end{tabular}

\section{Nyquist plots}

The inhibition effect, electrochemical impedance spectroscopy was well suited for monitoring in situ any perturbation by an inhibitor according to the electrochemical processes in the interface of metal/corrodent. The influence of $\mathrm{Zn}^{2+}$ on the adsorption of carbon steel, high corrosion inhibition effect of surfactant and the synergistic effect of the two have been studied. Figs. 5 and 6 shows Nyquist curves of without and with an inhibitor formulation $\left(\mathrm{CTAB}+\mathrm{Zn}^{2+}\right.$ \& DTAB + $\mathrm{Zn}^{2+}$ ), it is well known that the semi - circle diameter of the Nyquist plot is proportional to the anticorrosion behaviour. Large diameter reveals better anticorrosion performance.

The main fitting parameters for Nyquist curves data obtained for the substrate and samples immersed in well water are listed in Tables 5 and 6 , a great improvement on the corrosion resistance of the substrate was obtained for $\left(\mathrm{CTAB}+\mathrm{Zn}^{2+} \& \mathrm{DATB}+\mathrm{Zn}^{2+}\right)$ samples with a high total resistance $\mathrm{R}_{\text {ct. }}$. Namely, the $\left(\mathrm{CTAB}+\mathrm{Zn}^{2+}\right.$ \& $\left.\mathrm{DTAB}+\mathrm{Zn}^{2+}\right)$ films acts as good barrier facing against the penetration of well water, subsequently enhancing the anticorrosion behaviour of carbon steel. The inhibition efficiency (I.E.) calculated from $\mathrm{R}_{\mathrm{ct}}$ reaches a considerable percentage. For studying the synergism parameters of $\left(\mathrm{CTAB}+\mathrm{Zn}^{2+}\right)$ and $\left(\mathrm{DTAB}+\mathrm{Zn}^{2+}\right)$, surfactants with co-adsorption of $\mathrm{Zn}^{2+}$, the synergism parameter $\mathrm{S}_{\mathrm{I}}$ is defined as follows [17].

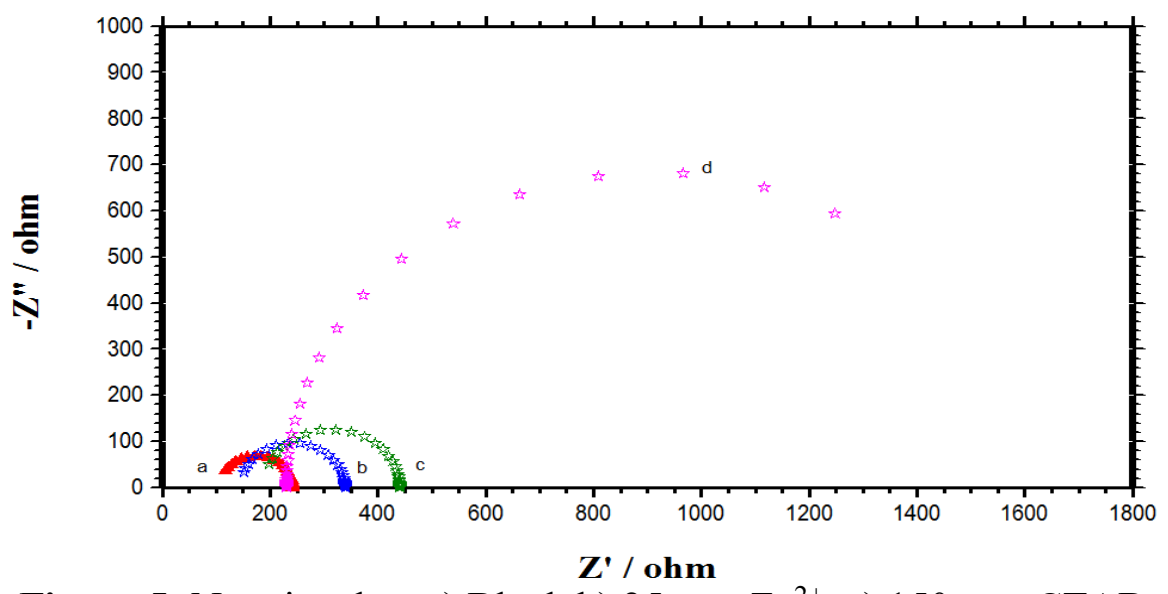

Figure 5: Nyquist plots a) Blank b) 25ppm $\mathrm{Zn}^{2+}$ c) $150 \mathrm{ppm} \mathrm{CTAB}$ d) $25 \mathrm{ppm} \mathrm{Zn}^{2+}+150 \mathrm{ppm} \mathrm{CTAB}$ 


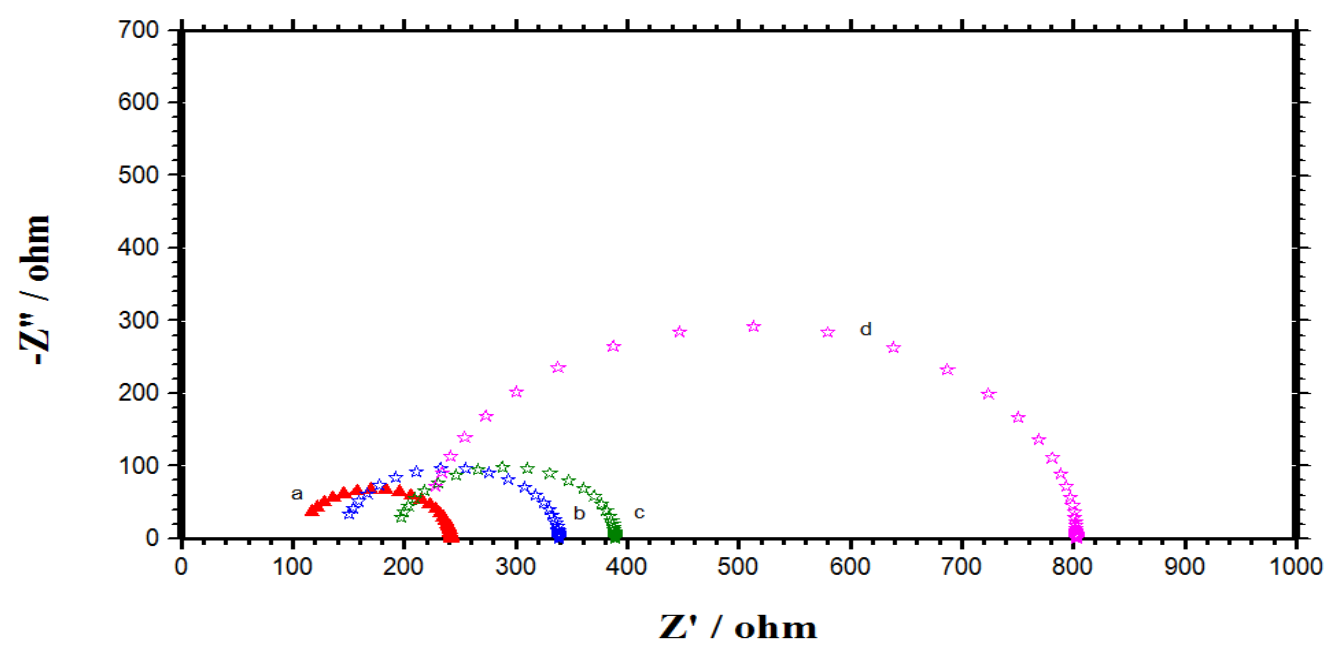

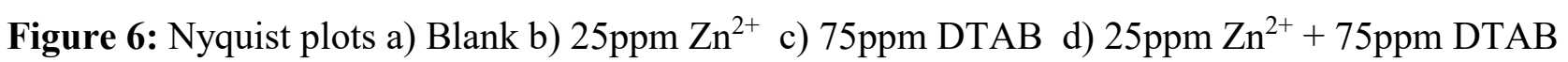

Table 5: Electrochemical parameterss, inhibition efficiency (IE) and synergism parameter $\left(\mathrm{S}_{\mathrm{I}}\right)$ from the impedance study for carbon steel in well water

\begin{tabular}{|c|c|c|c|c|c|c|}
\hline $\begin{array}{c}\text { Conc. of } \\
\mathrm{Zn}^{2+}(\mathrm{ppm})\end{array}$ & $\begin{array}{c}\text { Conc. of } \\
\text { CTAB } \\
(\mathrm{ppm})\end{array}$ & $\begin{array}{c}\mathrm{R}_{\mathrm{ct}} \\
\text { ohm.cm }\end{array}$ & $\begin{array}{c}\mathrm{C}_{\mathrm{dl}} \\
\mathrm{F}_{\mathrm{cm}}{ }^{-2} \times 10^{-5}\end{array}$ & $\% \mathrm{IE}_{\mathrm{imp}}$ & $\begin{array}{c}\text { Surface } \\
\text { coverage } \\
(\theta)\end{array}$ & $\begin{array}{c}\text { Synergism } \\
\left(\mathrm{S}_{\mathrm{I}}\right)\end{array}$ \\
\hline Blank & - & 135.10 & 17.290 & - & - & - \\
\hline- & 25 & 168.13 & 10.580 & 19.64 & 0.1964 & - \\
\hline 150 & - & 180.69 & 9.371 & 25.23 & 0.2523 & - \\
\hline 150 & 25 & 1330.0 & 0.174 & 89.84 & 0.8984 & 5.9133 \\
\hline
\end{tabular}

Table 6: Electrochemical parameterss, inhibition efficiency (IE) and synergism parameter $\left(\mathrm{S}_{\mathrm{I}}\right)$ from the impedance study for carbon steel in well water

\begin{tabular}{|c|c|c|c|c|c|c|}
\hline $\begin{array}{c}\text { Conc. of } \\
\mathrm{Zn}^{2+}(\mathrm{ppm})\end{array}$ & $\begin{array}{c}\text { Conc. of } \\
\text { DTAB } \\
(\mathrm{ppm})\end{array}$ & $\begin{array}{c}\mathrm{R}_{\mathrm{ct}} \\
\text { ohm.cm }\end{array}$ & $\begin{array}{c}\mathrm{C}_{\mathrm{dl}} \\
\mathrm{F}_{\mathrm{cm}} \mathrm{cm}^{-2} \times 10^{-5}\end{array}$ & \%IE imp & $\begin{array}{c}\text { Surface } \\
\text { coverage } \\
(\theta)\end{array}$ & $\begin{array}{c}\text { Synergism } \\
\left(\mathrm{S}_{\mathrm{I}}\right)\end{array}$ \\
\hline Blank & - & 135.10 & 17.290 & - & - & - \\
\hline- & 25 & 168.13 & 10.580 & 19.64 & 0.1964 & - \\
\hline 75 & - & 174.81 & 10.415 & 22.71 & 0.2271 & - \\
\hline 75 & 25 & 584.64 & 0.914 & 76.89 & 0.7689 & 2.6875 \\
\hline
\end{tabular}

Where

$$
\mathrm{S}_{\mathrm{I}}=\left(1-\mathrm{I}_{1+2}\right) /\left(1-\mathrm{I}^{\prime}{ }_{1+2}\right)
$$

$\mathrm{I}_{1+2}=\left(\mathrm{I}_{1}+\mathrm{I}_{2}\right)-\left(\mathrm{I}_{1 \times \mathrm{I}_{2}}\right)$

$\mathrm{I}_{1}=$ surface coverage of inhibitors (surfactants)

$\mathrm{I}_{2}=$ surface coverage of inhibitors $\left(\mathrm{Zn}^{2+}\right)$

$\mathrm{I}_{1+2}^{\prime}=$ combined surface coverage of inhibitors (surfactants) and $\left(\mathrm{Zn}^{2+}\right)$

\section{Mechanism of corrosion inhibitor}

Character of the counter ions on the adsorption of cationic surfactants is important factor. The possible adsorption of organic cations in the presence of the bromine ion is due to the formation of intermediate bridge, the negative ends of the bromine metal dipoles being oriented towards the interface of solution, whereby setting up an additional potential difference between the metal surface/ interface. This will shift the zero charge potential positively. 


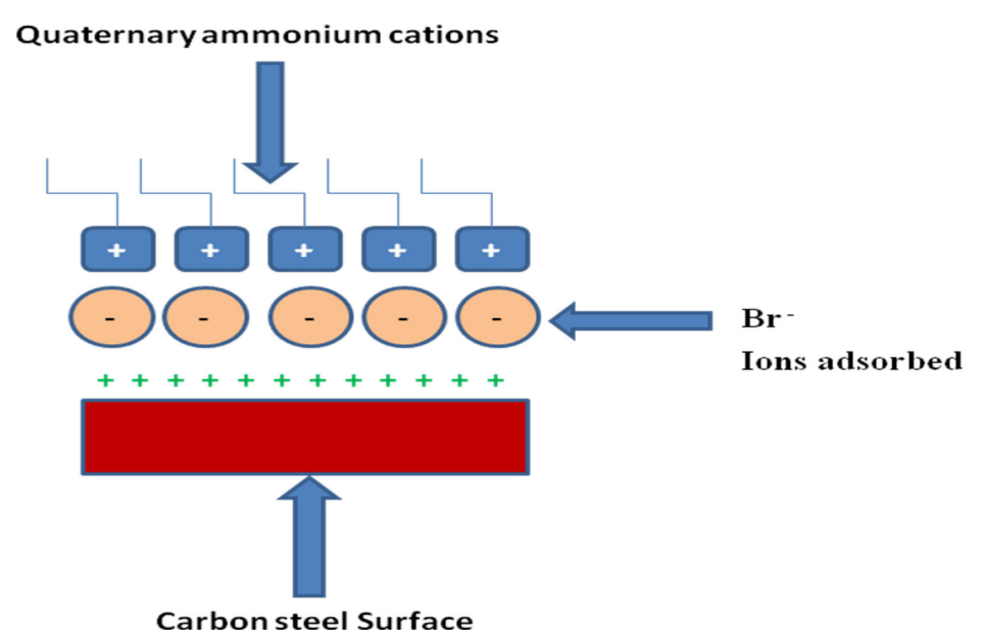

Figure 7: The schematic diagram of adsorption of surfactants on carbon steel surface

This shift will make the charge on the metal surface more negative and facilitates the adsorption of positively charged quaternary ammonium compound by formation of covalent bonds. Hard acid and hard base interaction and soft acid $\left(\mathrm{Fe}^{2+}\right)$ and soft base $\left(\mathrm{Br}^{-}\right)$interaction gives much more stable according to Pearson's rule. High hardness of $\mathrm{Br}^{-}$ion (counter ion effect) and cationic part of CTAB and DTAB to occur (cooperative effect with $\mathrm{Zn}^{2+}$ ) leads to high inhibition efficiency. $\mathrm{Br}^{-}$ion acts as an adsorption mediator for bonding the two positive partners, the metal surface and the positively charged ammonium compound. This gives rise to the formation of an adsorption composite film in which the anions are sandwiched between the metal surface and positively charged part of the inhibitor [18]. This film acts as a barrier facing the corrosion process as shown in Fig. 7. From above, it is mentioned that a hydrophilic head group of chosen surfactants. Inhibition efficiency of CTAB is larger than DTAB may be due to;

i. $\mathrm{Br}^{-}$(soft base) is a borderline base attached with a borderline acid $\left(\mathrm{Fe}^{2+}\right.$ surface) and soft acid (bulk iron metal surface) according to Pearson classification of acid and base.

ii. $\mathrm{Br}^{-}$ion is more hydrophobic, with large ionic radius and low electro negativity. $\mathrm{N}-\mathrm{Br}$ bond loosely bonded. Thus it adsorbed more tightly on carbon steel surface.

iii. The alkyl chain of CTAB is longer than DTAB. The greater will be the forces of attraction between the alkyl chains of adjacently adsorbed head group ions [19].

\section{Conclusion}

1. The investigated surfactants protect the corrosion of carbon steel in well water

2. The protection is due to adsorption of the surfactant molecules on the carbon steel surface and blocking its active regions.

3. Results shows from weight loss, Tafel curves and Nyquist plots are in reasonably good agreement and inhibition efficiency order of CTAB $>$ DTAB.

4. Tafel curves shows that the investigated surfactants acts as an anodic inhibitor in well water 5. The FT - IR and AC impedance spectra confirm the formation of protective film on the carbon steel surface.

\section{References}

[1] G. Blustein, J. Rodriguez, R. Romanogli, C.F. Zinola, Corros. Sci. 47 (2005) 369-383.

[2] M. Mousavi, M. Mohammadalizadeh, A. Khosravan, Corros. Sci. 53 (2011) 3086-3091.

[3] V.M. Abbasov, H.M. Abd El-Lateef, Aliyeva LI, Ismayilov IT, Qasimov EE, Journal of the Korean Chemical Society. 2013;57(1):25-34. 
[4] V.M. Abbasov, H.M. Abd El-Lateef, L.I. Aliyeva, I.T. Ismayilov, NACE corrosion 2013, Florida, USA, paper No. 2129:1-10.

[5] H.M. Abd El-Lateef, V.M. Abbasov, L.I. Aliyeva, E.E. Qasimov and I.T. Ismayilov, Journal of Surfaces and Interfaces of Materials. 2012;1:1-11.

[6] H.M. Abd El-Lateef, V.M. Abbasov, L.I. Aliyeva, I.T. Ismayilov, E.E. Qasimov, Ahmadov TU, J. Phys. Chem. 2012;3(14):1-12.

[7] J.M. Bastidas, P. Pinilla, J.L. Polo, S. Miguel, Corros. Sci. 45, (2003), 427.

[8] A.E. Bolzán, I.B. Wakenge, R.C.V. Piatti, R.C. Salvarezza, A.J. Arvia, J. Electroanal. Chem. 501, (2001), 241.

[9] E. Stipnisek-Lisac, A. Gazivoda, M. Madzarac, Electrochim. Acta 47, ( 2002), 4189.

[10] M. Sahin, S. Bilgic, H. Yilmaz, Appl. Surf. Sci. 195, (2002), 1.

[11] M. Houyi, C. Shenhao, Y. Bingsheng, Z. Shiyong, L. Xiangqian, Corros. Sci. 45, ( 2003$), 867$.

[12] M.L. Free, Corros. Sci. 44,( 2002), 2865.

[13] M.L. Free, Corrosion 58, (2002), 1025.

[14] C. Thangavelu, P. Patric Raymond, S. Rajendran and M. Sundaravadivelu, Asian J. Research Chem. 4(3), (2011), 402-405.

[15] C. Thangavelu, M. Umarani, M. Sekar, P. Patric Raymond, RASAYAN.J.Chem. 4(2011), 245250.

[16] C. Thangavelu, P. Patric Raymond, S. Rajendran and M. Sundaravadivelu, Asian J.Research Chem. 4(7), (2011), 1033-1037.

[17] H. Tavakoli, T. Shahrabi, M.G. Hosseini, Mater. Chem. Phys. 109 (2008) 281-286

[18] V.S. Sastri, J.R. Perumareddi, Corros. Sci, 53 (1997) 617.

[19] T.Y. Soror, M.A. El-Ziady, Mater. Chem. Phys, 77(2002) 702. 